\title{
Arts and Environmental Conservation: Study of Kentrung Art in Jepara
}

\author{
Alamsyah $^{*}$, Siti Maziyah \\ Department History, Faculty of Humanities, Diponegoro University, Semarang - Indonesia
}

\begin{abstract}
Kentrung art is one of arts that exist on Jepara coast. This is a speech art played by two people using beaten instruments such as terbang or tambourines. Kentrung is not only a fiction for entertainment, but also contains a pasemon (parable) or human life symbols. This art center is located in Ngasem village, Batealit, Jepara. Kentrung proponents are elderly or old people (wong lawas) who activate kentrung art in Jepara. Old people is as a representation of ancient people or the people who do not following the times. As the older person, one of their life view is to respect nature preservation. Their respect for the environment is reflected in the activities that are often asked to perform in earth alms events considered at the time of alms and the insertion of kentrung stories that are often delivered between the plays that are being performed. Even though it is not dominant, love expression of the performer and the arts towards the environment is seen in the insertion of the stage.
\end{abstract}

Keywords. Kentrung, Jepara, Wong Lawas, Living Environment

\section{Introduction}

Coastal communities are communities that have high creativity. The structure of coastal communities is very plural, so that they are able to form a system and cultural values which are the cultural acculturation from each component that forms the structure of the community [1]. Jepara community is a type of coastal community that has various arts which still exist today. One of them is kentrung.

Kentrung is a speech art (storytelling) about folklore which have special characteristics. Kentrung is storytelling art wrapped in music, comedy rhymes, songs, and advice that is close to daily life, including the environment. Kentrung as a product of ancient or old people culture, can explain many representations that reflect the identity (religion and social systems) and various expressions of life experiences that illustrate their specific life principles [2]. This art has an important role in providing a moral education, religion, environment, and appreciation to folklore in its every performance [3].

\footnotetext{
*Corresponding author: alam_mahir@yahoo.com
} 
The origin of Kentrung Jepara art according to the oral tradition of Jepara community, its emergence and development began in Ngasem Village area, Batealit District, which located in the western Jepara city. The majority of Ngasem people work as farmers as their livelihood. At the very beginning of kentrung presence, the village community, especially kentrung arts proponents, considered themselves as old-fashioned (out-of-date), or people who are identified with obsolete term. The Community life is far from the frenetic urban life and urban pop culture. The old people (out-of-date) in Ngasem can be seen from their physical characteristics that appear from their mindset, the daily behavior of each individual, their typical society, and what they do as their livelihood [4]. However, at this time kentrung proponents and Ngasem community have experienced many changes and are open to modernity, especially the younger generation.

In this context, Kentrung proponents and performers are old people, so it illustrates their attitudes and behavior, that are the old (out-of-date) society. The old (out-of-date) people very respects and preserves their environment because their life dependent on the environment, which agricultural and plantation products. So it's natural if this art in its performance often inserts the importance of enviromental preservation for people's life. On the other hand, kentrung performance is often held in traditional earth alms activities in villages. This tradition is a form of gratitude expression to God who has given abundant nature gifts while drawing closer to nature.

\section{Method}

This study is a qualitative research with a lot of emphasis on observation aspects, interviews, and secondary source search. In the data collection stage, the main source is obtained from the previous studies both online and library visits. After the data is collected, the next step is criticizing the sources whether the data is suitable or not. To obtain data that supports each other, the efforts made are by interpreting or analyzing various sources that have been available [5]. The next stage is to reconstruct the research results into an article entitled "Arts and Environmental Conservation: Study of Kentrung Art in Jepara" [6].

\section{Results and Discussion}

\subsection{Kentrung Art in Jepara}

Kentrung art is a form of folk storytelling theater performed by Kentrung puppeteer. The story told by the puppeteer is in the form of prose that sung, interspersed with rhymes (parikan) which are also sung, and musical instruments (tambourines) are used [7]. Kentrung art performance is as if only the sound of tambourine musical instruments combined with human voices answer to each other by telling folklore and rhymes that were sung traditionally. However, if it seen more deeply about the contents of the message conveyed in Kentrung story which is an oral literature (oral folklore) it can be beneficial for the listener and the audience as one of the cultural heritages and inserted with environmental preservation [8].

Kentrung art is full of philosophical values and has an important role in providing a moral education, religion, and appreciation to folklore in its every performance [9]. The story showed in Kentrung is not just a fictional story for entertainment, this story contains a parable or symbol of human life that is close to everyday environments. The story perpetrators are the hereditary thoughts and feelings of the Javanese for generations so that the Kentrung performance plays an important role in the Javanese society movement in general [10]. 


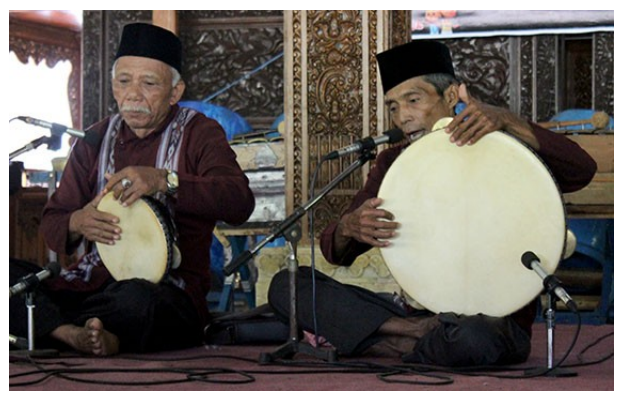

Documentation: radarkudus.jawapos.com

Fig. 1. Parmo dan Madi was performing on stage of The Opening Ceremony of The Kentrung Festival, Jepara 2017

Kentrung player consists of a puppeteer and several people as panjak. Panjak is Kentrung art member who is in charge to beat Kentrung instruments and giving intermezzo in the form of parikan and shout (senggakan). The position of panjak can also be handled by the puppeteer because he can tell the story while beat Kentrung instrument, especially kendang instrument [11]. Kentrung performance is not just a fiction for an entertainment but also contains a parable or symbol of human life. The story plays an important role in Javanese society movement in general and the rural people in particular. That's why the story is used by people for various purposes like moral teachings up to the environment teachings [12]. Story in Kentrung's performance is adjusted to the invitees' needs, usually Kentrung is invited to the baby party, wedding, circumcision party, vow, and earth alms.

Kentrung is expected to emerge during Demak sultanate in the 16th century, whose territory encompassed the north coast of Central Java and East Java [13]. Kentrung development is not only in the northern coastal region, but also developed in other East Java regions such as in Sidoarjo, Kediri, Blitar, and Ponorogo [14]. Kentrung also developed in Jepara around 1935 which was originally used as a da'wah media spread Islam [15]. In the 1930 s, Kentrung was a folk art with a large population in Jepara. In the 1950 s to 1980 s, the art population was gradually shrinking. In the 1980s until now (2020), Kentrung art only leaves one group that still works [16]. According to oral traditions known by Jepara people, Kentrung emerged and developed in the Ngasem Village area, Batealit, Jepara. The art proponent community called themselves as old people [17].

\subsection{Old (Out-of-date) People the Kentrung Art Originator}

Kentrung art in Jepara cannot be separated from Ngasem community people or the old people. The community believes that Kentrung Jepara's art emerged and developed in Ngasem, Batealit, Jepara. Ngasem people with unique characters are often referred to old peopleor people who are identified as 'out of date' people. Ngasem people in their daily lives are far from the frenetic urban life and urban pop culture. Old people in Ngasem can be seen from their physical characteristics that showed from their mindset, daily behavior of each individual, typical association, and what they do as their livelihood [18].

Old people in Ngasem allegedly still exist today. The old people still exist in Jepara, even some of them are still consistent to maintain their old life ideology even though they are able and have many opportunities to change their lifestyle (improve their welfare). The old people who consistently maintain their identity as the out-of-date people can still be recognized in their life ideas and some behaviors as their manifestations. The old people in the independence era until now still has a quirky idea that distinguishes them from other people in general in Jepara even though their physical performance is same [19]. 
The old people have a characteristic that cannot be lost, that is their life ideas. The old people still survive until now because there are some people who are still consistent with past life ideas. Jepara in the past is an agrarian culture (farmers or fishermen) as its life idea, while nature as the back of life, and fertility is a source life survival. The old people who have an agrarian culture are certainly to be farming communities or farmers or traditional fishermen. The old people have a social life pattern who lives with social capita, not capita money. For the old people living peacefully with neighbors is vital, wealth is not their life goal but peace of life as a pillar of survival [20].

The old people live side by side with the community just like the others. They do not live in groups and do not make a specific community. The Old people are one part of the Javanese community in general who live in rural areas. The old expression shows the strong and firm qualities of their stance that received from their ancestors. Old is a mindset that become the holds of people who live as Kentrung art proponents. This mindset eventually affects the old people behavior who tend not to want to accept opinions and are not so influenced by the modernization and globalization flows. The old people can be said as a part of traditional Javanese society that still lives in certain areas more specifically in rural environments. The old people follow the mythic symbol, while their life norm is communal. [21].

Ngasem village is believed to be the forerunner and the center of Kentrung's development in Jepara. This is indicated by the existence of Kentrung puppeteer who was born and resides in Ngasem village, such as Sumo, Sukir, Subari, Karisan, and Suparmo. In Jepara communitie's view in general, there is a relationship between Kentrung's life and the existence of old people. This connection is not a general impression that has no reason, because even though Kentrung art is considered as 'out of date' art, but for its supporting community its existence is still needed today. Many Jepara people still invite Kentrung to perform in their family ritual or village ritual events. The Jepara people also still believe that Kentrung's performance is a guide, as well as a form of the old people expression of the old wong [22].

\subsection{Kentrung Art and the Environment}

Local wisdom is a form of environmental wisdom found in social life in a place or region, which refers to certain localities and communities [23]. Local wisdom is also values system or behavior of local people in interacting with their environment where they live wisely. Local wisdom is not same for different places, times and tribes. This difference is caused by the nature challenges and the different life needs, so that their experience in fulfilling his life's needs creates various knowledge systems both related to the environment and social [24]. Local wisdom has a characteristic of incorporating policy knowledge that teaches about ethics and moral values, comes from older community members, and teaches to love and preserve nature [25]. This is reflected in kentrung art which often inserts about environmental preservation in its performance.

Kentrung Jepara's arts also get a direct touch from the old people communities local wisdom in Ngasem. The care touch for the environmental is reflected in its performance such as when it performs in earth alms in villages and the insertion about environmental awareness in its performance. The symbols that appear in Kentrung arts are not only in the form of musicality, but it's more like the speech symbols expressions (stories that are told) and other symbols used to express aspects desired by the local community [26].

The old people think that industrial culture in Jepara which give impacts on the natural exploitation is as a betrayal to the ancestor culture (agrarian culture) who was earnestly preserving the nature. This group undertakes to live in a sustainable nature to achieve their goal that is heaven's happiness [27]. Kentrung Art accepts the love values for nature from 
the creators the Old People community. So it's natural when kentrung as a part of local wisdom becomes a media for nature conservation efforts.

Kentrung which is often performed in Earth Alms event in villages reflects that this activity is a gratitude expression from the community for the crops get from Allah SWT. Earth Alms is also an approach to the environment so that it continues to be taken care and preserved. The values contained in the earth alms activity is the love values for natural environment as the evidence of people's love for Allah SWT [28]. Kentrung which is performed on the earth alms activity will surely present stories or play relating to nature and the surrounding nature preservation. On the other hand, the relation between kentrung art and the environment is reflected in the insertion of environmental awareness delivered during the performance. Through this effort, it can be seen the contribution of kentrung art to the environmental preservation.

\section{Conclusion}

Kentrung art is a form of folklore theater delivered by two people, a puppeteer and panjak (instrumet player). Kentrung performances are also accompanied by terbang or tambourines beats. Kentrung is an oral literature that is useful for the listeners and the viewers as one of the cultural heritages. The story delivered in Kentrung performance is not only a fictional story for entertainment, the story also contains a parable or symbol of human life which is often inserted with environmental preservation efforts in its performance. Based on the oral tradition of Jepara people, Kentrung emerged and developed in Ngasem Village area, Batealit, Jepara. Ngasem people with their unique character and call themselves as the outof-date or the old people. They consistently maintain their identity as old people through their life idea, that is agrarian culture (farmers or fishermen) as their ideas of life. The old people consider nature as the back of life and fertility is a source of survival. The old people think that industrial culture give impact on the nature exploitation and as a betrayal to the ancestors culture (agrarian culture) who was earnestly in preserving nature. The old people undertakes to live in a sustainable nature to achieve the happiness goal. The relation between the kentrung and the environment is reflected in its performances in the villages during the earth alms and the insertion about environmental awareness on its performance.

\section{Acknowledgement}

The research is funded by DIPA Diponegoro University in 2020 budget year.

\section{References}

1. Wahyudin, Yudi, Sistem Sosial Ekonomi dan Budaya Masyarakat Pesisir (2003)

2. Wrahatnala, Bondet, Seni Kentrung Dan Masyarakat (Pandangan Dan Prinsip Hidup Masyarakat Yang Terekspresikan Dalam Seni Kentrung), Jurnal Pengkajian dan Penciptaan Seni

3. Harwanto, Dody Candra dan Sunarto, Bentuk dan Struktur Kesenian Kentrung di Jepara, Resital, Vol. 19 No. 1, April (2018)

4. Wrahatnala, Bondet, Kebertahanan Kentrung Dalam Kehidupan Masyarakat Jepara (2017)

5. Garraghan, Gilbert, A Guide to Historical Method (1947)

6. Herlina, Nina, Metode Sejarah (2008)

7. Sumardjo, Jakob. Perkembangan Teater Modern dan Sastra Drama Indonesia (1997) 
8. Harwanto, Dody Candra dan Sunarto, Bentuk dan Struktur Kesenian Kentrung di Jepara, Resital, Vol. 19 No. 1, April (2018)

9. Harwanto, Dody Candra dan Sunarto, Bentuk dan Struktur Kesenian Kentrung di Jepara, Resital, Vol. 19 No. 1, April (2018)

10. Hutomo, Suripan S., Kentrung Warisan Tradisi Lisan Jawa, (1998)

11. Hutomo, Suripan Sadi, Cerita Kentrung Sarahwulan di Tuban, (1993)

12. Hutomo, Suripan Sadi, Cerita Kentrung Sarahwulan di Tuban, (1993)

13. Sumardjo, Jakob. Perkembangan Teater Modern dan Sastra Drama Indonesia, (1997)

14. Hutomo, Suripan Sadi, Sinkretisme Islam-Jawa: Studi Kasus Seni Kentrung Suara Seniman Rakyat

15. Manggala, Bondan Aji, Seni Orang “Kuno” (Suker) Jepara, (2011)

16. Harwanto, Dody Candra dan Sunarto, Bentuk dan Struktur Kesenian Kentrung di Jepara, Resital, Vol. 19 No. 1, April (2018)

17. Wrahatnala, Bondet, Kebertahanan Kentrung Dalam Kehidupan Masyarakat Jepara, (2017)

18. Wrahatnala, Bondet, Kebertahanan Kentrung Dalam Kehidupan Masyarakat Jepara, (2017)

19. Manggala, Bondan Aji, Seni Orang “Kuno” (Suker) Jepara, (2011)

20. Manggala, Bondan Aji, Seni Orang “Kuno” (Suker) Jepara, (2011)

21. Wrahatnala, Bondet, Kebertahanan Kentrung Dalam Kehidupan Masyarakat Jepara, (2017)

22. Wrahatnala, Bondet, Kebertahanan Kentrung Dalam Kehidupan Masyarakat Jepara, (2017)

23. Suhartini, Kajian Kearifan Lokal Masyarakat Dalam Pengelolaan Sumberdaya Alam Dan Lingkungan, (2009)

24. Akhmar, Andi M. dan Syarifuddin, Mengungkap Kearifan Lingkungan Sulawesi Selatan, (2007)

25. Mungmacon, Roikhwanphut, Knowledge and Local Wisdom: Community Treasure, (2012)

26. Manggala, Bondan Aji, Seni Orang “Kuno” (Suker) Jepara, (2011)

27. Manggala, Bondan Aji, Seni Orang “Kuno” (Suker) Jepara, (2011)

28. Sufia, Rohana; Sumarmi; Ach. Amirudin, "Kearifan Lokal Dalam Melestarikan Lingkungan Hidup", Jurnal Pendidikan: Teori, Penelitian, dan Pengembangan Volume 1 No. 4, April, (2016) 